\title{
Related Party Transactions and Financial Performance: Is There a Correlation? Empirical Evidence from Italian Listed Companies
}

\author{
Matteo Pozzoli ${ }^{1}$, Marco Venuti ${ }^{2}$ \\ ${ }^{1}$ Università degli Studi di Napoli “Parthenope”, Napoli, Italy \\ ${ }^{2}$ Università degli Studi di "Roma Tre", Roma, Italy \\ Email: matteo.pozzoli@uniparthenope.it, marco.venuti@uniroma3.it
}

Received October 30, 2013; revised December 2, 2013; accepted December 10, 2013

Copyright (C) 2014 Matteo Pozzoli, Marco Venuti. This is an open access article distributed under the Creative Commons Attribution License, which permits unrestricted use, distribution, and reproduction in any medium, provided the original work is properly cited. In accordance of the Creative Commons Attribution License all Copyrights (C) 2014 are reserved for SCIRP and the owner of the intellectual property Matteo Pozzoli, Marco Venuti. All Copyright (c) 2014 are guarded by law and by SCIRP as a guardian.

\begin{abstract}
Related party transactions (RPTs) can have a dual nature. On one hand, these transactions may be considered sound business exchanges, fulfilling the economic needs of the company. On the other hand, RPTs may be considered a mechanism to exploit company resources as a consequence of existing conflicting interests. This study takes into account both aspects. Specifically, this paper investigates the relation between RPTs and companies' financial performance, and thus verifies whether there is an association between these kinds of transactions and earnings management. This study examines the existence of this relation as regards the universe of Italian listed companies for the period of 2008-2011. According to the related data analysis, the research concludes that related party transactions and companies' financial performance results are not correlated and that there is no evidence of a cause-effect relation. Therefore, related party transactions do not appear-thanks also to the existence of control mechanisms - a means used by Italian listed companies to realize earnings management, especially earnings smoothing.
\end{abstract}

\section{KEYWORDS}

Related Party Transactions; Earnings Management; Accounting Standards; Corporate Governance

\section{Introduction}

Related party transactions (RPTs) are defined as "a transfer of resources, services or obligations between a reporting entity and a related party, regardless of whether a price is charged" (IAS 24). The definition of "related party" substantially includes controlling shareholders, directors and every other group which can exercise a degree of influence over the company (such as affiliates, joint ventures and close members of the related party's family). A related party may enter into transactions with the related company using different economic terms compared to an independent party. In other words, a related party may use these transactions to transfer resources in or out of the company thanks to its influence on the company's decisions.

RPTs can have a dual nature. On one hand, these transactions may be considered sound business exchanges, fulfilling the economic needs of the company. They represent internal dealings able to reduce transaction costs and increase efficiency through the creation of an internal market within the corporate group [1-4]. The literature refers to this kind of RPT as "propping" or "efficient transaction hypothesis". On the other hand, RPTs may be considered a mechanism to exploit company resources as a consequence of existing conflictual interests. In particular, such a transaction may be carried out in the interest of insiders, i.e. directors and controlling shareholders, in order to expropriate wealth from outside investors, i.e. non-controlling shareholders (NCSs) [1,3,59]. According to this view, such transactions may imply the misuse of company's resources (moral hazard) and the misrepresentation of private information (adverse 
selection). The literature refers to this kind of RPT as "tunnelling" or "conflict of interests transaction hypothesis".

Owing to the dual effect of RPTs, this paper does not focus only on one of these potential effects (tunnelling or propping view), but it analyses all the financial effects arising from RPTs.

In particular, this paper investigates relation between RPTs and financial performance within Italian listed companies, and thus verifies whether there is an association between these kinds of transactions and earnings management ${ }^{1}$.

In fact, RPTs might be an instrument to carry out a deliberate alteration of periodic company reporting. One of the objectives of this alteration might consist in maintaining earnings stable and substantially constant over the time, i.e. "earnings smoothing" [14]. In this case, there would be an inverse relation between financial effects of RPTs and companies' earnings, so that related party profits increase when companies' financial performance decreases, and vice versa.

This study examines the existence of this relation as regards the universe of the above mentioned Italian listed companies for the period of 2008-2011. The "Italian case" appears to be significant in this field of research, because Italy has developed, in recent years, a sort of monitoring mechanism in order to avoid inappropriate RPTs, so as to safeguard potential and existing investors.

Using the collected data, the analysis concludes that financial performance and RPT results are not correlated and that there is no evidence of a cause-effect relation. RPTs do not appear to be a means used by Italian listed companies to realize earnings management, especially earnings smoothing.

The remainder of the paper proceeds as follows: the next section contains a literature review, whilst Section 3 provides institutional background about the market analyzed. Section 4 lays out the hypothesis, Section 5 illustrates the methodology applied, and Section 6 presents the empirical findings. Finally, Section 7 concludes the paper.

\section{Survey Literature}

Regulators, standard setters, investors and other corporate stakeholders commonly regard RPTs as a potential risk of abuse that could harm a company's value and thus the efficiency and transparency of the market. They also recognise the importance of having an adequate system

\footnotetext{
${ }^{1}$ Healy and Wahlen [10] assert that "earnings management occurs when managers use judgment in financial reporting and in structuring transactions to alter financial reports to either mislead some stakeholders about the underlying economic performance of the company, or to influence contractual outcomes that depend on reported accounting numbers”. See also: [11-13].
}

of control to avoid opportunistic behaviour. However, this does not exclude the fact that RPTs can be economically beneficial, especially in institutional contexts without efficient capital, labour and product markets, such as in many developing economies. These transactions might be an instrument to optimize the economic activity of each company in the context of a group trying to minimize transaction costs caused by local market inefficiencies $[15,16]$. For this reason, there is no legislation that completely forbids RPTs [17]. In fact, local jurisdictions regulate these transactions in different ways but only RPTs that present a notably real risk of potential abuse are banned, such as loans to directors [18].

In literature, numerous studies support these views.

A large number of studies analyse the market reaction experienced by listed companies when they announce different types of RPTs [19-24]. Analyzing Chinese companies, Xiao and Zhao [25] find that the stock return decreases around RPTs. This effect is particularly significant for some kinds of transactions, notably loan guarantees and direct fund transfers. In a study about Hong Kong, Cheung et al. [7] show that the companies that realize value-destroying RPTs continue to decline in value for up to 12 months following the transaction. This finding suggests that investors penalize these companies for a long time following the RPT announcement. In research about the United States of America, Kohlbeck and Mayhew [26] indicate a negative impact on stock market valuations for companies which disclose RPTs in financial reporting compared to those that do not make disclosures because presumably they have none.

Some authors investigate the means used by insiders to tunnel companies' resources. Cheung et al. [27] indicate that companies acquire assets from related parties at a higher price and also sell at a lower price in comparison to similar arms' length transactions. Therefore, RPTs appear to transfer resource away from the NCSs of listed companies [8,9].

Some empirical research identifies specific channels through which expropriation of resources could be realized, such as, unreliable related party sales [28], abnormal accruals associated with certain types of transactions such as those involving fixed-rate financing from related parties [29], extension of loan guarantees to related parties [30], loans which have below-market interest rates [31], private securities offerings by industrial groups [20], excessive executive compensation [17] and generous credits provided when the company has exceeding cash [32].

Other literature does not support the tunnelling view. In some research, RPTs are considered a mechanism to promote and preserve the company's assets (propping view). Peng et al. [33] show that markets react favourably to the announcement of transactions between com- 
pany and controlling shareholders when the company is in financial distress. Friedman et al. [34] demonstrate that it is optimal for entrepreneurs to support the company when there is a moderate adverse shock, so that it continues to stay in business. Buysschaert [35] finds that intra-group equity transactions create value for NCSs.

Other empirical studies find different effects depending on the different circumstances. Jian and Wong [32] investigate RPTs as a means to earnings management. They find that Chinese listed companies use related party sales to manage earnings in order to meet the government's return on equity (ROE) requirements during the initial public offering (IPO) process or to avoid being delisted. In addition, listed companies divert resources obtained from transactions to their major shareholders through related loans. This view is also supported by Aharony et al. [36] who show that post-IPO abnormal stock returns that are negative correlate with the extent of RPTs with the parent company $[37,38]$.

Focusing on the dual effect of RPTs, it is sometimes difficult to determine if transactions are beneficial or detrimental to company performance. Some studies find no evidence of positive or negative effects stemming from RPTs. For example, Kuan et al. [39] do not find evidence of a relationship between RPTs and earnings management.

Generally speaking, the results are not always clear or consistent $[27,40]$. This stems from the difficulty of using appropriate variables and measuring them accurately. Many times, variables cannot be measured so a proxy is used. This introduces uncertainty and errors in variables. It also takes into consideration that internal dealings may interact with and be influenced by legal and regulatory frameworks-such as procedures for RPTs, disclosures, independent directors, external and internal audits, board or shareholder approval, enforcement-and other factors-such as geographical and cultural differences, sector and size.

Some studies show that poor NCS protection-and hence weak corporate governance-penalizes companies' valuation [3,22,23,41] and business performance [23]. Other studies indicate that regulations on related party disclosure mitigate the negative effects of self-dealing $[42,43]$ and reduce the ability of insiders to remove companies' assets secretly [26]. When RPTs are monitored and have to be disclosed, insiders may avoid engaging in these problem-creating transactions, even when the company would benefit [44]. Lin et al. [24] indicate that the existence of control mechanisms may mitigate the negative effect of RPTs, which result in expropriation of the company's NCSs. Particularly, Cheung et al. [27] show that the presence of an audit committee on the company's board appears to limit expropriation [21,45].
This evidence suggests that strong NCS protection mitigates the risks of potential abuse but also of potential benefits. This statement is consistent with the conclusion of research regarding the relationship between earnings management and NCS protection. A large number of studies demonstrate that "earnings management decreases in legal protection because, when NCS protection is strong, insiders enjoy fewer private control benefits and, consequently, incentives to mask firm performance are moderate” ([46], see also: [11,47-49]).

In the light of the specifics of each country, the OECD [18] suggests the development of a model on a single jurisdiction to avoid that single local factors add significant errors [50]. Following this suggestion, this paper investigates the relation between RPTs and companies' performance focusing only on Italian listed companies.

\section{Institutional Background}

Italy has a high concentration level of ownership and strong NCS protection, notably for RPTs [18].

As regards the degree of corporate control of listed companies, this has remained substantially constant in spite of considerable strong evolution in NCS protection, as shown in Table 1.

In recent years, Italy has significantly enhanced NCS protection by introducing new laws and regulations for transparency and approval. Italy has passed from weak NCS protection [48] to strong NCS protection [18] ${ }^{2}$.

Currently, Italy has a special requirement that is applied to RPTs entered into by listed companies, and other specific rules to protect NCSs. For example, there are provisions covering: independent directors, monitoring procedures of RPTs, internal and external audits, restrictions regarding directors' ability to manage the company in the interest of dominant shareholders, and disclosures about RPTs.

In this process, the introduction of IAS/IFRS (International Accounting Standards/International Financial Reporting Standards)-and therefore IAS 24 for disclosure about RPTs-has favoured a correct disclosure to investors. In fact, Italian listed companies are obliged to apply IAS/IFRS in publishing their consolidated financial statements and also-with the exception of insurance compa-

\footnotetext{
${ }^{2}$ This change started with the Draghi reform for listed companies (1998) followed by: the new company law (2003), the so called Parmalat law ("law of saving" 2003) and other specific rules introduced by different legislation. In this context, it's also important to note the Italian Budget Law for 2008 which introduced new rules where IAS/IFRS adopters' taxable income is more closely linked to international accounting rules. In the meantime, Consob (the Italian Securities Regulator) issued different rules regarding the ongoing issue of NCS protection and RPTs. In addition, the Italian Code of Corporate Governance (the so called Prada code) - first adopted in 1999 and later amended various times, the latest in 2011—contains provisions about this issue.
} 
Table 1. Ownership concentration of Italian listed companies": (a) 1998-2008; (b) 2009-2011.

(a)

\begin{tabular}{cccc}
\hline & 1998 & 2003 & 2008 \\
\hline Largest shareholder & $46.7 \%$ & $44.7 \%$ & $45.5 \%$ \\
$\begin{array}{c}\text { Other relevant } \\
\text { shareholders }\end{array}$ & $14.1 \%$ & $17.3 \%$ & $18.3 \%$ \\
Dispersed ownership & $39.2 \%$ & $38.0 \%$ & $36.2 \%$ \\
\hline
\end{tabular}

(b)

\begin{tabular}{cccc}
\hline & 2009 & 2010 & 2011 \\
\hline Largest shareholder & $45.7 \%$ & $44.6 \%$ & $44.8 \%$ \\
$\begin{array}{c}\text { Other relevant } \\
\text { shareholders }\end{array}$ & $17.0 \%$ & $17.7 \%$ & $17.4 \%$ \\
Dispersed ownership & $37.4 \%$ & $37.7 \%$ & $37.7 \%$ \\
\hline
\end{tabular}

Source: Based on Consob data. "Simple average.

nies-individual financial statements ${ }^{3}$. In addition to IAS 24 requirements, Consob (the Italian Securities Regulator) requires Italian listed companies to indicate, if material, the amount realized with related parties for each item directly in the accounting formats-i.e. statement of financial position, comprehensive income, changes in equity and cash flows-and report the financial effects from RPTs in a specific quantitative table included in the notes.

Furthermore, Italy is a country with strong links between taxation and financial reporting rules. The Italian legislation considers the result of the income statement set forth in the IAS/IFRS as an appropriate indicator to use, adopting some changes, for tax purposes [51]. It means that there is also a process of tax verification on certain aspects of (individual) financial statements, such as transfer prices, and hence another form of control on companies' decisions concerning RPTs.

Last but not least, the Italian government has also in-

${ }^{3}$ Italy is one of the Member States that has made greater use of the options provided by the European Regulation 1606/02/EC, imposing or permitting the application of the IAS/IFRS (International Accounting Standards/International Financial Reporting Standards) in relation to a large number of companies. Based on Legislative Decree 38/05 publicly accountable companies-listed companies, companies issuing financial instruments widely distributed to the public, banks and other regulated financial institutions - are obliged to apply the IAS/IFRS in publishing both their consolidated and individual financial statements. Within such a broad group of companies, the only exception is insurance companies, whose obligation is restricted solely to their consolidated financial statements. The non-publicly accountable companies are instead permitted to adopt the IAS/IFRS in their consolidated and individual financial statements. This option can be exercised by: the consolidated subsidiaries of enterprises bound to apply the IAS/IFRS; companies preparing consolidated financial statements and their consolidated companies; and remaining companies with the exception of small companies. As a matter of fact, however, the option cannot be exercised by these "remaining" companies until a ministerial decree has been issued on the subject. Moreover, this option is not available to small companies since the use of IAS/IFRS is prohibited to them. troduced severe criminal sanctions against illegal selfdealing.

The characteristics of the Italian market indicate a potential low level of tunnelling and propping effects caused by the existence of a wide disclosure in financial statements about RPTs, as well as strong NCS protection. According to this view, Italy provides an important setting to test whether, in this situation, RPTs effectively do not influence companies' financial performance.

\section{Hypothesis}

Based upon the results of the studies mentioned in Section 3 and Italian legislation, it is possible to propose the following research hypothesis:

Companies' financial performance and RPTs are not correlated. This means that there is no evidence of a cause-effect relation between these variables.

In this case this hypothesis was proved. It was affirmed that the NCS protection safeguards, including the disclosure requirements, are effective and have a positive impact on Italian listed companies' regular transactions.

In other words, the research provides evidence that RPTs are not used by Italian companies to influence their performance and realize earnings management. In this view, the existence of an appropriate control mechanism permits monitoring and mitigating of the "artificial" effect arising from RPTs as a consequence of a tunnelling or propping activity. In general terms, it can be assumed that insiders - and mainly controlling shareholdersprefer, in line with the "efficient transaction hypothesis", sustaining working costs rather than avoiding the risk to incur potential higher costs in terms of credibility and financial loss, and legal prosecution.

In the case that the company's financial performance and the RPTs highlighted a direct relation, the RPTs profitability trend could confirm the company's trend. Specifically, if the financial effects of RPTs increase more (or decrease less) than a company's performance, it could be possible to affirm that RPTs permit companies to create adequate efficiencies and synergies, facilitating coordination among involved entities.

Lastly, in the case that the research found an indirect relation between the variables, RPTs could be addressed as an accounting policy instrument and could be undertaken to have a window dressing effect on financial statements (earning smoothing).

\section{Methodology}

This study takes into consideration the universe of listed Italian companies, which have publicly listed their equity instruments during the period 2008-2011, and which have published their consolidated financial statements in the above mentioned period. 
The listed Italian companies are regulated by the Borsa Italiana SpA, which is a company dedicated to the organization and management of the Italian financial markets. The Borsa Italiana SpA has been part of the London Stock Exchange Group since 2007. In line with the Borsa Italiana databank, the whole universe of companies whose instruments are listed in the Italian financial market ("Mercato Telematico Azionario") numbered at 255 as of November 30, 2012.

It is important to briefly present the composition of the Italian financial market, because this analyses can lead us to a segment analysis of the relation between RPTs and financial performance. The mentioned Italian financial market can be grouped into specific segments, measured by related indices (the so-called FTSE).

The research does not address listed investment vehicles (closed-end fund vehicles and investment companies) traded in the ad hoc "Mercato Telematico degli Investment Vehicles".

The addressed data have been taken from the relevant companies' websites. It is important to mention that Consob requires listed companies to publish their financial reports on their websites, in order to achieve a high level of transparency.

There are 185 Italian listed companies that have satisfied the requirements. This means that the companies satisfying the above criteria represent approximately $72 \%$ of the examined universe.

Exclusions have been mainly determined by the following reasons:

- companies that do not publish consolidated financial statements. The research has privileged the consolidated accounts, as the financial community usually takes into first consideration the group financial statements. In addition, most of the foreign issuers listed in the Italian regulated market and in another financial market (dual-listed companies), or in other financial markets (multi-listed companies), only publish their consolidated financial statements;

- companies controlled by other listed companies. In this circumstance, the research takes into account only the parent company's consolidated financial statements, considering that the parent's consolidated accounts include controlled entities' data as well. If the research had addressed subsidiaries' consolidated financial statements, it would have risked counting the same operations twice and, consequently, to mislead the data analysis;

- companies that have not presented costs or revenue from RPTs in the formats and notes of the consolidated financial statements. In this case, the financial effects linked to the RPTs have been considered by the companies as immaterial. The inclusion of these companies in the research would have been illogical from a statistical perspective, because the data has presented no change in the examined period;

- the required financial effects linked to RPTs have been illustrated by the companies in an inconsistent manner throughout the years. In this case, the disclosure is not fully coherent or complete during the years and the required data cannot be rigorously determined. This could be due to the fact that the listing of companies occurred after 2008 or there has been a discontinuity in financial reporting during the analysed years as a consequence of business combinations or liquidation processes.

As far as the variables analysis is concerned, this research intends - as already stated - to find evidence as to whether RPTs profits (or losses) are directly or inversely related to financial performance.

The correlation is measured by the index of Pearson:

$$
r=\frac{\sum_{i=1}^{n}\left(x_{i}-\bar{x}\right)\left(y_{i}-\bar{y}\right)}{\sqrt{\sum_{i=i}^{n}\left(x_{i}-x\right)^{2} \sum_{i=1}^{n}\left(y_{i}-y\right)^{2}}}
$$

The variables $x$ and $y$ are respectively related to the profit (or loss) arising from RPTs and to the entities' financial performance, measured, in this circumstance, by the ratio of the Return on Assets (ROA).

It is important to recall that both variables are taken from the published companies' financial statements. The analysis cannot have any objections on the financial statements' data and must assume that they are reliable and faithful.

The variable $x$ represents the profit (or loss) from RPTs (PL RPTs), meant as the balance between the total revenue from RPTs and the total costs arising from RPTs. The variable $y$ identifies the company's performance, and it is represented by the Return on Assets (ROA). This ratio relates the company's operating profit with its total assets.

Return on Assets $=\frac{\text { Earnings before Interests and Taxes }}{\text { Total Assets }}$

Earnings before Interests and Taxes (EBIT) measure the company's operating performance. Accounting literature and accepted industry practices address EBIT as one of the most important financial indicators for investors' needs [52-55].

As concerns insurance companies, banks and other regulated financial institutions, the research has used the profit (or loss) before tax from continuing operations in place of the EBIT. Financial institutions are not used to applying EBIT to measure their performance, as it would exclude the financial area from the determination of the entity's performance, the area, that is the most significant for this kind of entity. The profit (loss) before tax from 
continuing operations has been taken without addressing the tax effects, in order to be consistent with the above mentioned EBIT.

ROA has been addressed as an appropriate ratio identifying companies’ performance, as:

- it is generally accepted within the financial community as a significant ratio;

- it can be calculated without expressing discretional judgment upon its determination; in this context it was preferred to other ratios and, in primis, to Return on Investments (ROI), meant as the ratio between the EBIT and the invested capital. Specifically, the invested capital could be determined by different assumptions, perspectives and methods. Due to this, the adoption of a ratio calculated without a consistent and uniform basis would have affected the collection of data. Obviously, as mentioned before, the research has not performed inquiries on the appropriateness of the data of the involved financial indicators.

The variable $x$ naturally affects the variable $y$, as the financial effects related to RPTs affect the company's EBIT and, therefore, participates in the determination of the ROA's numerator. Only 40 companies out of the 185 companies examined in the research have presented revenue from RPTs higher than $2 \%$ of the total turnover for the four examined periods. Essentially, the impact of the determination on the variable $y$ by the variable $x$ can be addressed as immaterial.

The correlation previously exposed is specifically converted as it follows:

$$
r=\frac{\sum_{i=1}^{n}\left(P L R P T s_{i}-\overline{P L R P T}\right)\left(R O A_{i}-\overline{R O A}\right)}{\sqrt{\sum_{i=i}^{n}\left(P L R P T_{i}-x\right)^{2} \sum_{i=1}^{n}\left(R O A_{i}-R O A\right)^{2}}}
$$

\section{Data Analysis}

The correlation between the variables $x$, identifying the profit (or loss) from RPTs, and $y$, measuring the companies' ROA has been initially analyzed with specific reference to the periods 2008-2009, 2009-2010, and 20102011.

In the above mentioned cases, there is no evidence of any significant correlation between the variables $(-0.2<$ $r<0.2$ ). The existence of a direct or inverse correlation has been denied with reference to the separate analysis of the annual periods. Correlation results support the provided hypothesis. These results are consistent with the findings of some empirical analyses previously performed on local markets [24,27,43].

This circumstance can be confirmed by the observation of the following Figures 1 to 3 concerning the scatter correlation diagrams related to the cited annual variations. The dispersion diagrams relate to the variations of the analysed variables $x$ and $y$. In order to produce a

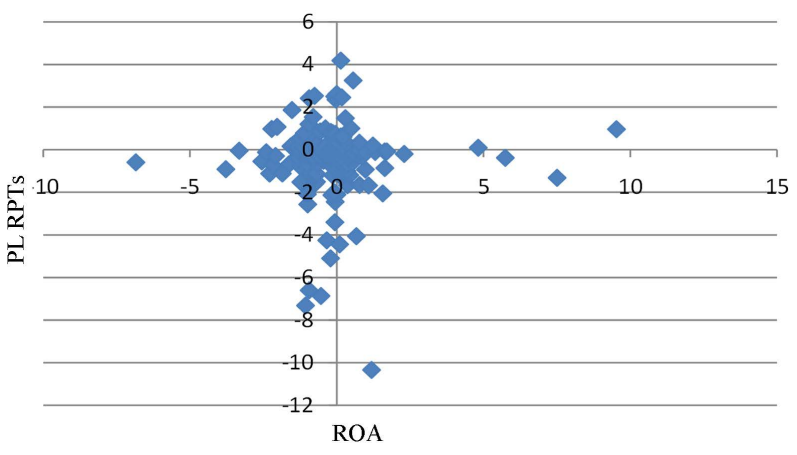

Figure 1. Scatter plot for the relation between RPTs profit (or loss) and companies' performance: period 2008-2009.

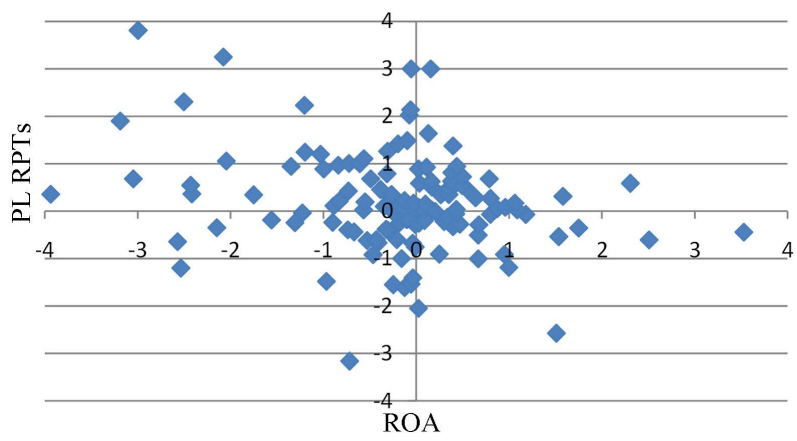

Figure 2. Scatter plot for the relation between RPTs profit (or loss) and companies' performance: period 2009-2010.

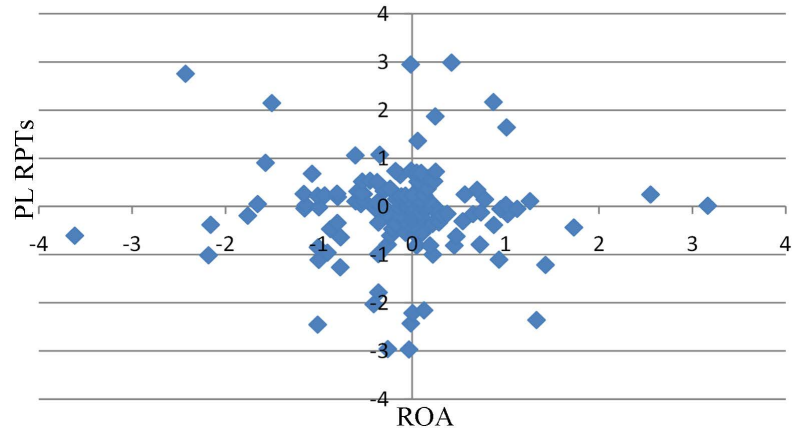

Figure 3. Scatter plot for the relation between RPTs profit (or loss) and companies' performance: period 2010-2011.

comprehensible diagram, the figures have excluded the companies, which present an average between the variable $x$ and the variable $x$ inferior to (or higher than) 5. This orientation has been conducted in order to exclude from the representation the limited cases (around 10\%), which are farthest and risk distorting the analysis.

The lack of correlation has been analysed, not only addressing the universe of listed companies' financial statements, but also referring the correlation to the companies included in the FTSE MIB and satisfying the predetermined and explained criteria.

The indices of the FTSE Italia All Share are adequately represented in the research, as the percentage of companies included in the group and the percentage fulfilling 
the provided conditions is substantially similar.

The financial community takes into due consideration the FTSE MIB index, because it includes the forty biggest capitalized companies representing-according to the Borsa Italiana calculation procedure [56]—around $80 \%$ of the Italian market capitalization.

There are 28 companies included in the FTSE MIB fulfilling the required criteria, which represent around $70 \%$ of the companies of this segment. This percentage is relatively lower than the percentage of FTSE Italia All Share satisfying the provided conditions, essentially because some companies included in the FTSE MIB belong to the same economic group and are represented in the same consolidated financial statements.

The examination of the $2009-2010$ period presents a slight direct correlation. The analysis can substantially confirm, as already affirmed by part of the literature, that larger and smaller listed companies have a similar attitude towards RPTs [57].

Lastly, the behavior of listed companies having material RPTs in the four examined periods have been investigated. In this view, the analysis has considered RPTs as "material", when the revenue arising from RPTs has been consistently superior to $2 \%$ of the company's turnover. This sub-group is composed of 40 companies. The research has found no relation in any period.

\section{Conclusions}

This paper contributes to the research of RPTs in different ways.

Firstly, the literature regarding the examined issue, the association between RPTs and earnings management, is still limited, and, in many cases, focused upon samples in local markets, such as East Asian countries (China, Indonesia, Malaysia and Taiwan) and the United States of America.

This paper carries out this analysis on Italian listed companies, and thus on a specific market within the European Union. In this way, this paper extends this kind of research to a different geographical area with diversity in jurisdiction and environmental contexts. This research contributes to covering another economy in order to enlarge the landscape of empirical studies.

Secondly, this research takes into consideration the entire financial effects arising from RPTs, presenting a quantitative analysis not affected by the typical problems of a proxy (uncertainty and errors in variables). The variables used are extrapolated from the involved official financial statements and can be addressed as free from discretional bias.

Thirdly, the study analyses the whole set of Italian listed companies satisfying the required criteria. This research addresses all cases rather than determining a sample set.
As regards the results of the conducted analysis, this research confirms that the hypothesis of tunnelling or propping effects tends to be less pronounced or absent in companies operating in a country-Italy-which has a strong local NCS protection. In particular, our results show that RPTs and companies' financial performance results are not correlated for Italian listed companies and that there is no evidence of a cause-effect relation. Therefore, RPTs do not appear a means used by Italian listed companies to perform earnings management, especially earnings smoothing.

Our study supports recommendations for strict regulations on NCS protection, notably for RPTs, in order to reduce non-transparent use of these transactions and, consequentially, a manipulation of earnings management. In addition, it has to be considered that RPTs have been under regulators' and authorities' attention, even if single cases can evidence that the mechanism cannot totally protect financial investors. In the last months a listed Italian insurance company (Sai Fondiaria) has been involved in a scandal regarding tunnelling transactions. This evidence does not contradict the result of this research. In a situation like this, Henry et al. [58] remark that the public opinion may reflect an "illusory correlation” i.e. when one perceives a casual relationship (also because of emotional impact), one tends to think that cooccurrence is more frequent than it actually may be. Frauds can be realized with or without RPTs however they relatively infrequent [59-63].

Although this study provides useful insights regarding the association between RPTs and earnings management, there are some limitations to consider. This research refers to a limited period of time, which has produced a relevant financial and economic crisis in Italy. In this context, the variation of the companies' performance (variable Y) has presented, in many circumstances, progressive decreases. Most of the above mentioned studies have been carried out in periods or contexts with a minor degree of turbulence, providing the chance to mix positive and negative financial conditions. A longer period of time could be more appropriate.

Another limitation concerns the fact that the analysis takes into consideration the total effect arising from RPTs; it is not said that within these transactions "propping” or "tunnelling” transactions are present. Our finding does not exclude that, in specific cases, these kinds of transactions may be used by insiders as instruments for "propping” or "tunnelling”.

\section{REFERENCES}

[1] S. Claessens, J. P. H. Fan and L. H. P. Lang, “The Benefit and Costs of Group Affiliations: Evidence from East Asia,” Emerging Markets Review, Vol. 7, No. 1, 2006, pp. 1-26. http://dx.doi.org/10.1016/j.ememar.2005.08.001 
[2] R. A. Coase, "The Firm, the Market and the Law," University of Chicago Press, 1937.

[3] E. A. Gordon, E. Henry and D. Palia, "Related Party Transactions and Corporate Governance," Advances in Financial Economics, Vol. 9, 2004, pp. 1-28. http://dx.doi.org/10.1016/S1569-3732(04)09001-2

[4] M. Jian and T. J. Wong, "Propping through Related Party Transactions," Review of Accounting Studies, Vol. 15, No. 1, 2010, pp. 70-105. http://dx.doi.org/10.1007/s11142-008-9081-4

[5] Y. Amzaleg and R. Barak, "Ownership Concentration and the Value Effect of Related Party Transactions,” 2011. http://ssrn.com/abstract=1959557

[6] A. A. Berle and G. C. Means, "The Modern Corporation and Private Property," The MacMillan Company, New York, 1932.

[7] Y.-L. Cheung, P. R. Rau and A. Stouraitis, “Tunneling, Propping and Expropriation: Evidence from Connected Party Transactions in Hong Kong,” Journal of Financial Economics, Vol. 82, No. 2, 2006, pp. 343-386. http://dx.doi.org/10.1016/j.jfineco.2004.08.012

[8] S. Johnson, P. Boone, A. Breach and E. Friedman, "Corporate Governance in the Asian Financial Crisis,” Journal of Financial Economics, Vol. 58, No. 1-2, 2000, pp. 141-186. http://dx.doi.org/10.1016/S0304-405X(00)00069-6

[9] S. Johnson, R. La Porta, F. Lopez-de-Silanes and A. Shleifer, “Tunneling," American Economic Review Papers and Proceedings, Vol. 90, 2000, pp. 22-27.

[10] P. M. Healy and J. M. Wahlen, "A Review of the Earnings Management Literature and Its Implications for Standard Setting,” Accounting Horizons, Vol. 13, No. 4, 1999, pp. 365-383. http://dx.doi.org/10.2308/acch.1999.13.4.365

[11] S. Callao and J. I. Jarne, "Have IFRS Affected Earnings Management in the European Union?" Accounting in Europe, Vol. 7, No. 2, 2010, pp. 159-189. http://dx.doi.org/10.1080/17449480.2010.511896

[12] P. Dechow and D. Skinner, "Earnings Management: Reconciling the Views of Accounting Academics, Practitioners, and Regulators,” Accounting Horizons, Vol. 14, No. 2, 2000, pp. 235-250.

http://dx.doi.org/10.2308/acch.2000.14.2.235

[13] A. Mechelli and R. Cimini, "L'effetto Dell'Introduzione dei Principi IAS/IFRS Sull'Earnings Management nei Paesi Dell’Unione Europea," Rivista Italiana di Ragioneria e di Economia Aziendale, Vol. CXII, No. 11-12, 2012, pp. 582-595.

[14] T. Onesti and M. Romano, "Earnings Management and Goodwill Accounting: Implications on Dividend Policy," Procediings of the $V$ Global and Business and Social Sciences Conference, Bejing, June 2012.

[15] S. J. Chang and U. Choi, "Strategy, Structure and Performance of Korean Business Group,” Journal of Industrial Economics, Vol. 37, No. 2, 1988, pp. 141-158. http://dx.doi.org/10.2307/2098561

[16] T. Khanna and K. Palepu, "Why Focused Strategy May be Wrong in Emerging Markets," Harvard Business Re- view, Vol. 75, No. 4, 1997, pp. 41-51.

[17] S. Djankov, R. La Porta, F. Lopez-de-Silanes and A. Shleifer, "The Law and Economics of Self-Dealing," Journal of Financial Economics, Vol. 88, No. 3, 2008, pp. 430-465. http://dx.doi.org/10.1016/j.jfineco.2007.02.007

[18] OECD, "Related Party Transactions and Minority Shareholder Rights,” 2012.

http://www.oecd.org/daf/ca/corporategovernanceprinciple $\mathrm{s} / 50089215$

[19] K. H. Bae, J. K. Kang and J. M. Kim, "Tunneling or Value Added? Evidence from Mergers by Korean Business Groups,” Journal of Finance, Vol. 57, No. 6, 2002, pp. 2695-2740. http://dx.doi.org/10.1111/1540-6261.00510

[20] J. S. Baek, J. K. Kang and I. Lee, "Business Groups and Tunneling: Evidence from Private Securities Offering by Korean Chaebols,” Journal of Finance, Vol. 61, No 5, 2006, pp. 2415-2449. http://dx.doi.org/10.1111/j.1540-6261.2006.01062.x

[21] A. A. W. Effiezal, H. Hasnah, L. L. Char and Y. Sofri, "Does Corporate Governance Matter? Evidence from Related Party Transactions in Malaysia,” In: J. Kose and K. M. Anil, Eds., International Corporate Governance, Advances in Financial Economics, Vol. 14, Emerald Group Publishing Limited, 2011, pp. 131-164. http://dx.doi.org/10.1108/S1569-3732(2011)0000014009

[22] W. Ge, D. H. Drury, S. Fortin, F. Liu and D. Tsang, "Value Relevance of Disclosed Related Party Transactions," Advances in Accounting, Vol. 26, No. 1, 2010, pp. 134-141. http://dx.doi.org/10.1016/j.adiac.2010.02.004

[23] D.-T. Huang and Z.-C. Liu, "A Study of the Relationship between Related Party Transactions and Firm Value in High Technology Firms in Taiwan and China," African Journal of Business Management, Vol. 4, No. 9, 2010, pp. 1924-1931.

[24] W.-Y. Lin, Y. A. Liu and I. Keng, "Related Party Transactions, Firm Performance and Control Mechanisms: Evidence from Taiwan," International Research Journal of Finance and Economic, No. 35, 2010, pp. 82-98.

[25] S. Xiao and S. Zhao, "How Do Agency Costs Affect Firm Value? Evidence from China,” 2012.

http://ssrn.com/abstract=1865306 http://dx.doi.org/10.2139/ssrn.1865306

[26] M. Kohlbeck and B. Mayhew, "Valuation of Firms that Disclose Related Party Transactions," Journal of Accounting and Public Policy, Vol. 29, No. 2, 2010, pp. 115-137. http://dx.doi.org/10.1016/j.jaccpubpol.2009.10.006

[27] Y.-L. Cheung, Y. Qi, P. R. Rau and A. Stouraitis, "Buy High, Sell Low: How Listed Firms Price Asset Transfers in Related Party Transactions," Journal of Banking \& Finance, Vol. 33, No. 5, 2009, pp. 914-924. http://dx.doi.org/10.1016/j.jbankfin.2008.10.002

[28] J. Wang and H. Yan, "The Impact of Related Party Sales by Listed Chinese Firms on Earnings Informativeness and Earnings Forecasts,” International Journal of Business, Vol. 17, No. 3, 2012, pp. 258-274.

[29] E. A. Gordon and E. Henry, "Related Party Transactions 
and Earnings Management,” 2005.

http://ssrn.com/abstract $=612234$

[30] H. Berkman, R. A. Cole and J. L. Fu, "Expropriation through Loan Guarantees to Related Parties: Evidence from China," Journal of Banking and Finance, Vol. 33, No. 1, 2009, pp. 141-156.

http://dx.doi.org/10.1016/j.jbankfin.2007.11.001

[31] K. Shastri and K. M. Kahle, “Executive Loans,” AFA 2004 San Diego Meetings, EFA 2003 Annual Conference Paper No. 184, 2004. http://ssrn.com/abstract $=423447$

[32] M. Jian and T. J. Wong, "Earnings Management and Tunneling through Related Party Transactions: Evidence from Chinese Corporate Groups,” Proceedings of American Accounting Association, Annual Conference Paper, 2004. http://dx.doi.org/10.2139/ssrn.424888

[33] W. Peng, J. K. C. Wei and Z. Yang, "Tunnelling or Propping: Evidence from Connected Transactions in China," Journal of Corporate Finance, Vol. 17, No. 2, 2011, pp. 306-325. http://dx.doi.org/10.1016/j.jcorpfin.2010.08.002

[34] E. Friedman, S. Johnson and T. Mitton, "Propping and Tunnelling,” Journal of Comparative Economics, Vol. 31, No. 4, 2003, pp. 732-750. http://dx.doi.org/10.1016/j.jce.2003.08.004

[35] A. Buysschaert, M. Deloof and M. Jegers, "Equity Sales in Belgian Corporate Groups: Expropriation of Minority Shareholders? A Clinical Study," Journal of Corporate Finance, Vol. 10, No. 1, 2004, pp. 81-103. http://dx.doi.org/10.1016/S0929-1199(02)00047-0

[36] J. Aharony, J. Wang and H. Yuan, "Tunneling as an Incentive for Earnings Management during the IPO Process in China," Journal of Accounting and Public Policy, Vol. 29, No. 1, 2010, pp. 1-26. http://dx.doi.org/10.1016/j.jaccpubpol.2009.10.003

[37] Y. M. Chen and C. Y. Chien, "Monitoring Mechanism, Corporate Governance and Related Party Transactions," 2007.

[38] L. Wu, Y. Wang, B. X. Lin and Y. Bai, "Full Privatization, Expropriation, and Firm Performance: Evidence from China,” Working Paper Series 3, College of Business Administration University of Rhode Island, 2009-2010.

[39] L. Kuan, G. Tower, Rusmin and J.-L.W. M. Van der Zahn, "Related Party Transactions and Earnings Management,” JAAI, Vol. 14, No. 2, 2010, pp. 115-137.

[40] M. Pizzo, "Related Party Transactions under a Contingency Perspective,” Journal of Management \& Governance, Vol. 17, No. 2, 2013, pp. 309-330. http://dx.doi.org/10.1007/s10997-011-9178-1

[41] R. La Porta, F. Lopez-De-Silanes, A. Shleifer and R. Vishny, "Investor Protection and Corporate Valuation," Journal of Finance, Vol. 57, No. 3, 2002, pp. 1147-1170.

[42] R. La Porta, F. Lopez-De-Silanes and A. Shleifer, "What Works in Securities Laws?” Journal of Finance, Vol. 61, No. 1, 2006, pp. 1-32.

[43] A. W. Y. Lo and M. K. Wong, "An Empirical Study of Voluntary Transfer Pricing Disclosures in China,” Journal of Accounting and Public Policy, Vol. 30, No. 6, 2011, pp. 607-628. http://dx.doi.org/10.1016/j.jaccpubpol.2011.08.005
[44] M. F. Chaghadari and Z. A. Shukor, "Corporate Governance and Disclosure of Related Party Transactions," Proceedings of the 2nd International Conference on Business and Economic Research, 14-16 March 2011.

[45] A. W. Y. Lo, M. K. Wong and M. Firth, "Can Corporate Governance Deter Management from Manipulating Earnings? Evidence from Related-Party Sales Transactions in China," Journal of Corporate Finance, Vol. 16, No. 2, 2010, pp. 225-235.

http://dx.doi.org/10.1016/j.jcorpfin.2009.11.002

[46] C. Leuz, D. Nanda and P. D. Wysocki, "Earnings Management and Investor Protection: An International Comparison,” Journal of Financial Economics, Vol. 69, No. 3, 2003, pp. 505-527.

http://dx.doi.org/10.1016/S0304-405X(03)00121-1

[47] A. Dyck and L. Zingales, "Private Benefits of Control: An International Comparison," Journal of Finance, Vol. 59, No. 2, 2004, pp. 537-600. http://dx.doi.org/10.1111/j.1540-6261.2004.00642.x

[48] R. La Porta, F. Lopez-De-Silanes, A. Shleifer and R. W. Vishny, "Law and Finance," Journal of Political Economy, Vol. 106, No. 6, 1998, pp. 1113-1155.

[49] M. Lang, J. S. Raedy and W. Wilson, "Earnings Management and Cross Listing: Are Reconciled Earnings Comparable to us Earnings?” Journal of Accounting and Economics, Vol. 42, No. 1-2, 2006, pp. 255-283. http://dx.doi.org/10.1016/j.jacceco.2006.04.005

[50] B. S. Blach, A. Gledson de Carvalho and E. Gorga, "What Matters and for Which Firms for Corporate Governance in Emerging Markets: Evidence from Brazil (and Other BRIK Countries),” Journal of Corporate Finance, Vol. 18, No. 4, 2012, pp. 934-952. http://dx.doi.org/10.1016/j.jcorpfin.2011.10.001

[51] M. Venuti, "Measuring Company Income Tax on the basis of the IAS/IFRS," British Tax Review, No. 4, 2010, pp. 361-375.

[52] V. Coda, M. Brunetti and M. Barbato Bergamin, "Indici di Bilancio e Flussi Finanziari,” Etas Libri, Milano, 1987.

[53] G. Ferrero, F. Dezzani, P. Pisoni and L. Puddu, "Analisi di Bilancio e Rendiconti Finanziari,” Giuffré, Milano, 2006.

[54] R. K. Jaedicke and R. T. Sprouse, "Accounting Flows: Income Funds and Cash,” Prentice-Hall, New Jersey, 1965.

[55] E. Schwartz, “Corporation Finance,” St. Martin’s Press, New York, 1964.

[56] Borsa Italiana, "Methodology for the Management of the FTSE MIB Index,” 2012. http://www.ftse.com/Indices/FTSE_Italia_Index_Series

[57] H. Chung and S. Kallapur, "Client Importance, Nonaudit Services, and Abnormal Accruals," The Accounting Review, Vol. 78, No. 4, 2003, pp. 931-955. http://dx.doi.org/10.2308/accr.2003.78.4.931

[58] E. Henry, E. A. Gordon, B. Reed and T. Louwers, "The Role of Related Party Transactions in Fraudulent Financial Reporting,” 2007. http://ssrn.com/abstract=993532 http://dx.doi.org/10.2139/ssrn.993532 
[59] T. Bell and J. Carcello, "A Decision Aid for Assessing the Likelihood of Fraudulent Financial Reporting," Auditing: A Journal of Practice \& Theory, Vol. 19, No. 1, 2000, pp. 169-184.

[60] S. Bonner, Z. V. Palmrose and S. Young, "Fraud Type and Auditor Litigation: An Analysis of SEC," The Accounting Review, Vol. 73, No. 4, pp. 503-532.

[61] E. Henry, E. A. Gordon, B. Reed and T. Louwers, "The Role of Related Party Transactions in Fraudulent Finan- cial Reporting," Journal of Forensic \& Investigative Accounting, Vol. 4, No. 1, 2012, pp. 186-213.

[62] SEC, "Report Pursuant to Section 704 of the SarbanesOxley Act of 2002,” Washington, 2003.

http://www.sec.gov

[63] S. Shapiro, "Wayward Capitalists: Targets of the Securities and Exchange Commision," Yale University Press, New Haven, 1984. 